\title{
Zinc Finger Proteins in the Human Fungal Pathogen Cryptococcus neoformans
}

\author{
Yuan-Hong $\mathrm{Li}^{1,2}$ and Tong-Bao Liu ${ }^{1,2, *(1)}$ \\ 1 State Key Laboratory of Silkworm Genome Biology, Southwest University, Chongqing 400715, China; \\ lyh5823@email.swu.edu.cn \\ 2 Chongqing Key Laboratory of Microsporidia Infection and Prevention, Southwest University, \\ Chongqing 400715, China \\ * Correspondence: tongbaoliu@swu.edu.cn; Tel.: +86-23-6825-1088
}

Received: 1 December 2019; Accepted: 13 February 2020; Published: 18 February 2020

\begin{abstract}
Zinc is one of the essential trace elements in eukaryotes and it is a critical structural component of a large number of proteins. Zinc finger proteins (ZNFs) are zinc-finger domain-containing proteins stabilized by bound zinc ions and they form the most abundant proteins, serving extraordinarily diverse biological functions. In recent years, many ZNFs have been identified and characterized in the human fungal pathogen Cryptococcus neoformans, a fungal pathogen causing fatal meningitis mainly in immunocompromised individuals. It has been shown that ZNFs play important roles in the morphological development, differentiation, and virulence of $C$. neoformans. In this review, we, first, briefly introduce the ZNFs and their classification. Then, we explain the identification and classification of the ZNFs in C. neoformans. Next, we focus on the biological role of the ZNFs functionally characterized so far in the sexual reproduction, virulence factor production, ion homeostasis, pathogenesis, and stress resistance in C. neoformans. We also discuss the perspectives on future function studies of ZNFs in C. neoformans.
\end{abstract}

Keywords: zinc finger proteins; Cryptococcus neoformans; fungal development; sexual reproduction; virulence

\section{Introduction}

Cryptococcus neoformans is a basidiomycetous yeast pathogen that causes fungal meningitis mainly in immunocompromised individuals [1]. C. neoformans is a ubiquitous fungal pathogen and can be found in soil, pigeon droppings, trees, fruits, and even human skin. Spores or desiccated yeast cells can be inhaled into the human lung to produce an asymptomatic infection that develops into a dormant latent infection [2]. When the host's immunity is impaired or reduced, the dormant form of the spores or desiccated yeast can be reactivated and disseminated from the lung to the central nervous system (CNS) to cause meningoencephalitis that is fatal without proper treatment [3]. With the increase in the number of people who have HIV or AIDS or who have received organ transplants and immunosuppressive therapy [4], C. neoformans infects more than one million people worldwide each year, resulting in hundreds of thousands of deaths annually $[5,6]$.

As a human fungal pathogen, $C$. neoformans has at least three major virulence factors: capsule formation, melanin production, and growth at $37^{\circ} \mathrm{C}$, which favors the infection and the pathogenesis of C. neoformans [7,8]. C. neoformans is a heterothallic basidiomycetous fungus, having two mating types, $\alpha$ and $\mathbf{a}$, and can undergo the transition from yeast-form to filamentous form by mating. During mating in C. neoformans, haploid cells of opposite mating types fuse to form dikaryotic filaments, leading to the formation of a basidium. After completion of meiosis inside the basidium, four chains of haploid basidiospores are produced on top of the basidium [2]. Under laboratory conditions, 
the $C$. neoformans cells of one mating type, e.g., $\alpha$ cells, can also fuse and undergo haploid fruiting to form filaments and basidiospores (see Figure 1) [2,9]. Based on capsular agglutination reactions, molecular studies, and genome sequences analysis, C. neoformans was classified into two varieties: C. neoformans var. neoformans (serotype D) and C. neoformans var. grubii (serotype A); a former third variety (C. neoformans var. gattii, serotype B) was reclassified as a separate species C. gattii [10-13]. Recently, based on the analysis of genealogical concordance, coalescence-based, and species tree approaches, some researchers proposed that the current $C$. neoformans var. neoformans and $C$. neoformans var. grubii can be recognized as separate species, C. deneoformans and C. neoformans, and the current C. gattii complex can be reclassified into five species [14]. Others recommend using "C. neoformans species complex" and "C. gattii species complex" to recognize genetic diversity and minimize the nomenclatural instability [15].

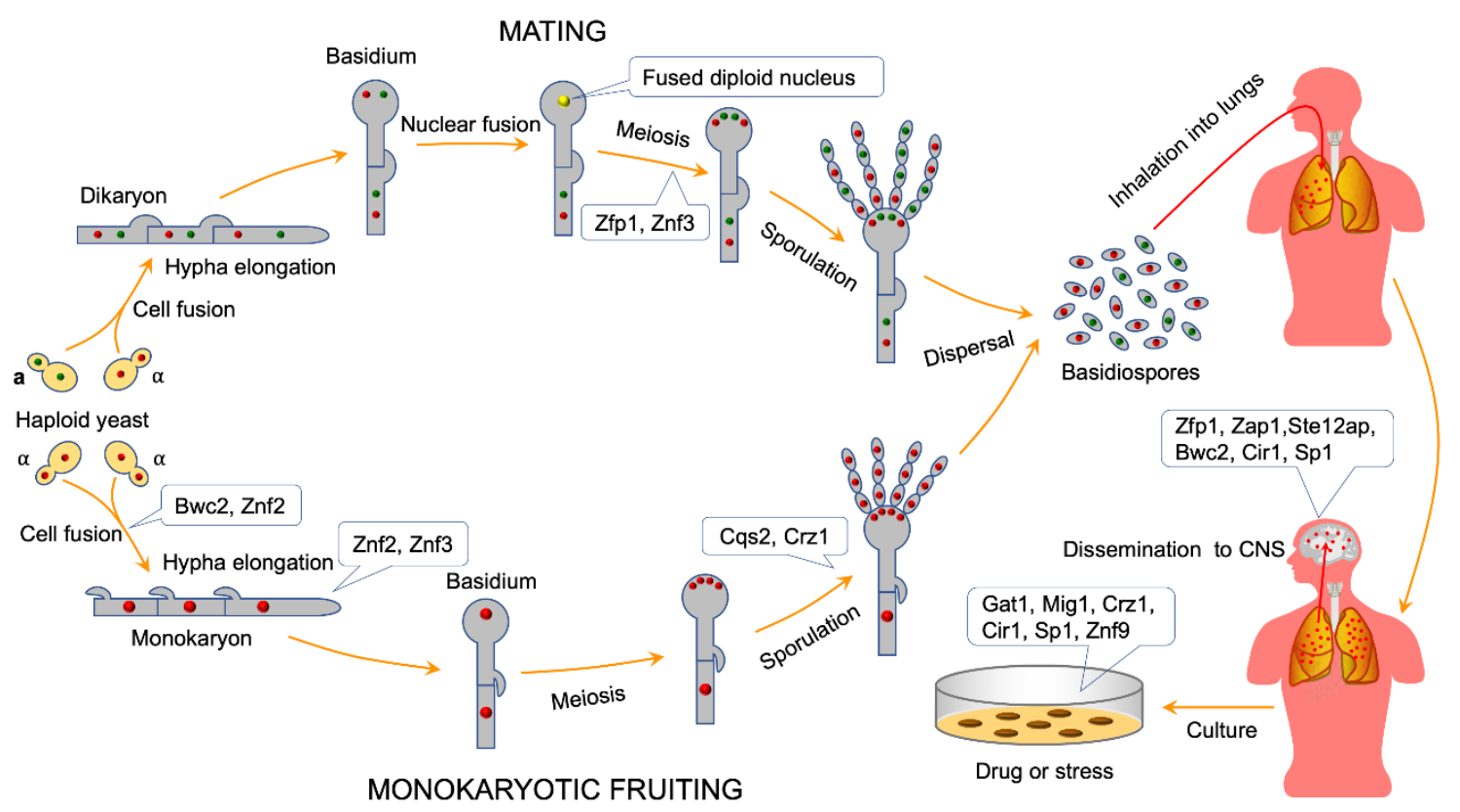

Figure 1. The biological function of zinc finger proteins (ZNFs) in C. neoformans. Under induction of nutrient-limiting conditions, $\alpha$ and a cryptococcal yeast cells can fuse and form dikaryotic filaments, leading to the formation of a basidium in which meiosis occurs to produce four chains of haploid basidiospores. Under laboratory conditions, C. neoformans cells of the $\alpha$ mating type can also fuse and undergo monokaryotic fruiting to produce filaments and basidiospores. The basidiospores can be inhaled into the lungs to establish a dormant infection or disseminate to the central nervous system to cause meningitis in humans. ZNFs are involved in different fungal development stages or processes, such as cell fusion, filamentation, sporulation, virulence, stresses, and light responses, in C. neoformans.

Up to now, many signaling pathways or factors involved in sexual reproduction and fungal virulence have been characterized and extensively studied [3,16-20]. However, these studies revealed that the regulation mechanism of fungal development and virulence in C. neoformans is very complicated and still need to be further explored.

ZNFs are zinc finger domain-containing proteins and form the most abundant proteins, serving extraordinarily diverse biological functions, such as transcriptional activation and regulation, protein degradation, signal transduction, and plenty of other functions [21]. Fungal ZNFs are best characterized in the budding yeast, Saccharomyces cerevisiae, where there have been more than 50 ZNFs identified in this organism based on the analysis of genome sequence data [22]. Among the ZNFs, Gal4 was the first and is the best studied ZNF and activates the genes responsible for galactose catabolism in S. cerevisiae $[22,23]$. ZNFs have also found and investigated in varieties of other fungal organisms, such as the fission yeast Schizosaccharomyces pombe and the human yeast-like pathogens Candida albicans 
and C. neoformans. In this review, we aimed to describe the identification and classification of ZNFs and summarize the current state of knowledge of ZNFs in the sexual reproduction, virulence factor production, metal homeostasis, pathogenesis, and stress resistance in the human fungal pathogen C. neoformans.

\section{Zinc Finger Proteins: An Overview}

ZNFs are wildly present in eukaryotes and participate in various cellular processes, including signaling transduction, gene activation and regulation, and cell differentiation. ZNFs are considered to be one group of proteins for they all harbor a common zinc finger motif, yet they display variable secondary structures and enormous functional diversity. A zinc finger is usually defined as a small, functional protein, with a structural motif that is coordinated by one or more zinc ions, and typically serves as an interactor module that binds DNA, RNA, proteins, or small molecules [21]. The zinc finger motif was initially identified as a repeated zinc-binding motif in the transcription factor IIIA (TFIIIA) in Xenopus laevis [24] and it was found to have a protruding "finger-like" shape a few years later by resolution of its three-dimensional solution structure [25]. Since then, numerous other ZNFs have been identified and functionally analyzed in many species, including pathogenic fungi. The majority of the ZNFs identified initially bind to DNA/RNA, suggesting a role in transcriptional and/or translational processes [21]. However, further study showed that ZNFs are not only limited to binding nucleic acids, but also are involved in many other physiological functions, such as regulating zinc sensing, chromatin remodeling, lipid binding, protein-protein interactions, and protein chaperoning [21,22].

ZNFs can coordinate divalent zinc ions with the combination of cysteine and histidine residues. Initially, based on the structural and functional variation of the zinc finger domain, ZNFs were categorized into at least nine types: $\mathrm{C}_{2} \mathrm{H}_{2}, \mathrm{C}_{2} \mathrm{HC}, \mathrm{C}_{3} \mathrm{H}, \mathrm{C}_{4}, \mathrm{C}_{6}, \mathrm{C}_{3} \mathrm{HC}_{4}, \mathrm{C}_{2} \mathrm{HC}_{5}, \mathrm{C}_{4} \mathrm{HC}_{3}$, and $\mathrm{C}_{8}$, in which $\mathrm{C}$ and $\mathrm{H}$ represent cysteine and histidine, respectively [26-28]. These nine types of ZNFs are summarized in Table 1. Most zinc finger proteins contain only one type of zinc finger, while other evolutionarily-conserved structural features were also identified outside the zinc finger domain in some ZNFs. The $\mathrm{C}_{2} \mathrm{H}_{2}$-type finger, represented by TFIIIA [24], is the classic zinc finger that has been best studied and is present in many transcription factors and other DNA-binding proteins [21]. $\mathrm{C}_{2} \mathrm{HC}$-type zinc finger domains, also referred to as retroviral-type (RT) zinc finger sequences, are required for viral genome packaging and RNA or single-stranded DNA binding in eukaryotes [29-33]. The C3H family proteins are divided into 18 groups based on the different amino acid spacing numbers between $C$ and $\mathrm{H}$ in zinc finger motif $[26,34,35]$. The $\mathrm{C} 4$ family includes seven types: GATA, FYVE, Tim10/DDP, LSD1, A20, TFIIB, and Zn-finger in Ran-binding protein [36]. GATA-1 was the first member of C4 family proteins characterized by the recognition of the GATA DNA sequence [37]. $\mathrm{C}_{3} \mathrm{HC}_{4}$-type finger, also termed RING finger, can be categorized into seven types with different conserved motifs, such as RING-H2, RING-HC, RING-v, RING-D, RING-S/T, RING-G and RING-C2 [38-40]. Many proteins with a RING finger play a vital role in the ubiquitination pathway [41,42]. The $\mathrm{C}_{2} \mathrm{HC}_{5}$ motif, also referred to as LIM, was first identified in the cell lineage gene lin-11 in Caenorhabditis elegans [43]. 
Table 1. The nine types of zinc finger domains.

\begin{tabular}{|c|c|c|c|c|}
\hline $\begin{array}{l}\text { Zinc-Binding } \\
\text { Domain Type }\end{array}$ & Consensus Sequence & Function & Examples & References \\
\hline $\mathrm{C}_{2} \mathrm{H}_{2}$ & $\mathrm{C}-\mathrm{X}_{2-4}-\mathrm{C}-\mathrm{X}_{12}-\mathrm{H}-\mathrm{X}_{3-5}-\mathrm{H}$ & $\begin{array}{l}\text { Transcription, } \\
\text { nucleic acid } \\
\text { binding }\end{array}$ & TFIIIA & [24] \\
\hline $\mathrm{C}_{2} \mathrm{HC}$ & $\mathrm{C}-\mathrm{X}_{2}-\mathrm{C}-\mathrm{X}_{4}-\mathrm{H}-\mathrm{X}_{4}-\mathrm{C}$ & $\begin{array}{l}\text { Genome packaging, } \\
\text { single-stranded } \\
\text { nucleic binding }\end{array}$ & $\begin{array}{c}\text { Retroviral } \\
\text { nucleocapsid }\end{array}$ & [29-33] \\
\hline $\mathrm{C}_{3} \mathrm{H}$ & $\begin{array}{c}\mathrm{C}-\mathrm{X}_{6-14}-\mathrm{C}-\mathrm{X}_{4-5}-\mathrm{C}-\mathrm{X}_{3}-\mathrm{H} \\
\mathrm{C}-\mathrm{X}_{2}-\mathrm{C}-\mathrm{X}_{17-}-\mathrm{C}-\mathrm{X}_{2}-\mathrm{C}\end{array}$ & $\begin{array}{l}\text { RNA binding } \\
\text { DNA binding }\end{array}$ & $\begin{array}{l}\text { Nup475 } \\
\text { GATA-1 }\end{array}$ & {$[26,34,35]$} \\
\hline $\mathrm{C}_{6}$ & $\begin{array}{c}C-X_{2}-C-X_{6}- \\
C-X_{6}-C-X_{2}-C-X_{6}-C\end{array}$ & $\begin{array}{l}\text { DNA binaing } \\
\text { DNA binding }\end{array}$ & $\begin{array}{l}\text { GAIA-1 } \\
\text { GAL4 }\end{array}$ & {$[44]$} \\
\hline $\mathrm{C}_{3} \mathrm{HC}_{4}$ & $\begin{array}{c}\mathrm{C}-\mathrm{X}_{2}-\mathrm{C}-\mathrm{X}_{9-39-\mathrm{C}-\mathrm{X}_{1-3^{-}}} \\
\mathrm{H}-\mathrm{X}_{2-3}-\mathrm{C}-\mathrm{X}_{2}-\mathrm{C}-\mathrm{X}_{4-48^{-}} \\
\mathrm{C}-\mathrm{X}_{2}-\mathrm{C}\end{array}$ & $\begin{array}{l}\text { Protein-protein } \\
\text { interaction, nucleic } \\
\text { acid binding }\end{array}$ & RING finger & {$[38-40,45]$} \\
\hline $\mathrm{C}_{2} \mathrm{HC}_{5}$ & $\begin{array}{c}\mathrm{C}-\mathrm{X}_{2}-\mathrm{C}-\mathrm{X}_{17-19-\mathrm{H}-\mathrm{X}_{2-}} \\
\mathrm{C}-\mathrm{X}_{2}-\mathrm{C}-\mathrm{X}_{2}-\mathrm{C}-\mathrm{X}_{16-20^{-}} \\
\mathrm{C}-\mathrm{X}_{2-3}-\mathrm{C}-\mathrm{C}-\mathrm{X}_{2}-\mathrm{C}-\mathrm{X}_{17^{-}} \\
\text {C- } \mathrm{X}_{2}-\mathrm{C}\end{array}$ & $\begin{array}{l}\text { Protein-protein } \\
\text { interaction, DNA } \\
\text { binding }\end{array}$ & $\begin{array}{l}\text { lin-11, isl- } 1 \text { and } \\
\text { mec-3 }\end{array}$ & [43] \\
\hline $\mathrm{C}_{4} \mathrm{HC}_{3}$ & $\begin{array}{c}\mathrm{C}-\mathrm{X}_{2}-\mathrm{C}-\mathrm{X}_{11-21}-\mathrm{C}-\mathrm{X}_{2}-\mathrm{C}- \\
\mathrm{X}_{4}-\mathrm{H}-\mathrm{X}_{2}-\mathrm{C}-\mathrm{X}_{14-17}-\mathrm{C}- \\
\mathrm{X}_{2}-\mathrm{C}\end{array}$ & $\begin{array}{l}\text { Transcription, } \\
\text { DNA binding }\end{array}$ & Requiem, ALL-1 & {$[46,47]$} \\
\hline $\mathrm{C}_{8}$ & $\begin{array}{c}\mathrm{C}-\mathrm{X}_{2}-\mathrm{C}-\mathrm{X}_{13}-\mathrm{C}-\mathrm{X}_{2}-\mathrm{C}- \\
\mathrm{X}_{15}-\mathrm{C}-\mathrm{X}_{5}-\mathrm{C}-\mathrm{X}_{12}-\mathrm{C}- \\
\mathrm{X}_{4}-\mathrm{C}\end{array}$ & $\begin{array}{l}\text { Oligomerization, } \\
\text { DNA binding }\end{array}$ & $\begin{array}{l}\text { steroid-thyroid } \\
\text { receptor }\end{array}$ & [48] \\
\hline
\end{tabular}

Then, the ZNFs were categorized into eight-fold groups based on the structural properties in the folded domain by a more systematic method [49]. Among these fold groups, the first three are Cys2His2-like, treble clef, and zinc ribbon, comprising the majority of zinc fingers $[49,50]$. Recently, based on the zinc-finger domain structure, 30 types of $Z N F$ s were classified and were approved by the Human Genome Organisation (HUGO) Gene Nomenclature Committee [51].

\section{ZNFs Identified in C. neoformans}

With the increase in the immunocompromised population resulting from AIDS and widespread immunosuppressive therapy, $C$. neoformans has become the main fungal pathogen in individuals with impaired immunity [1,52]. To better elucidate the genome basis for virulence in C. neoformans, the Cryptococcus research community has sequenced the genomes and/or transcriptomes of the two varieties of C. neoformans: C. neoformans var. neoformans (JEC21, serotype D) and C. neoformans var. grubii (H99, serotype A) [52,53], providing the data for the comparative analysis of the genomes of the isolates between the two serotypes. The Cryptococcus genome contains a large number of genes annotated to encode ZNFs. When we performed a keyword search combined with "zinc finger" or "zinc-finger", 127 and 129 genes encoding ZNFs were identified and characterized, according to the combination of cysteines and histidines, which coordinated $\mathrm{Zn}^{+2}$ ions in C. neoformans var. neoformans and C. neoformans var. grubii genome database, respectively (See Tables S1 and S2). Based on the distinct structural properties of the zinc finger motif, we have categorized the ZNFs identified in the C. neoformans genome database of both varieties (see Table 2). The functional annotation of ZNFs shows their critical biological roles in a diverse range of cellular processes, such as transcriptional regulation, protein transportation and degradation, chromatin remodeling, mRNA processing, and DNA binding and repairing. Thus, ZNFs may play crucial roles in fungal growth and development in C. neoformans. 
Table 2. Classification of ZNFs identified in genomes of $C$. neoformans var. neoformans JEC21 and C. neoformans var. grubii $\mathrm{H} 99$.

\begin{tabular}{ccccc}
\hline ZNF Type & No. of ZNFs in JEC21 & \% & No. of ZNFs in H99 & \% \\
\hline $\mathrm{C}_{2} \mathrm{H}_{2}$ & 28 & 22.0 & 28 & 21.7 \\
$\mathrm{C}_{4}$ & 28 & 22.0 & 32 & 24.8 \\
$\mathrm{C}_{3} \mathrm{HC}_{4}$ & 21 & 16.5 & 23 & 17.8 \\
$\mathrm{C}_{3} \mathrm{H}$ & 13 & 10.2 & 12 & 9.3 \\
$\mathrm{C}_{2} \mathrm{HC}$ & 10 & 7.9 & 12 & 9.3 \\
$\mathrm{C}_{6}$ & 5 & 3.9 & 4 & 3.1 \\
$\mathrm{C}_{4} \mathrm{HC}_{3}$ & 2 & 1.6 & 1 & 0.8 \\
$\mathrm{C}_{2} \mathrm{HC}$ & 1 & 0.8 & 1 & 0.8 \\
Combination & 6 & 4.7 & 6 & 4.7 \\
Others & 13 & 10.2 & 10 & 7.8 \\
Total & 127 & 100 & 129 & 100 \\
\hline
\end{tabular}

\section{ZNFs Regulate Sexual Reproduction in C. neoformans}

ZNFs form one of the largest families of transcriptional regulators, playing an essential role in the growth and development in eukaryotes. Over the past two decades, multiple signaling pathways, such as pheromone-sensing, light-sensing, cAMP/protein kinase A(PKA), calcineurin, and high-osmolarity glycerol (HOG) signaling pathways, regulating sexual reproduction and hyphal morphogenesis in C. neoformans, were identified and characterized via genetic and genomic approaches [18,54-57].

\subsection{ZNFs Regulate Cell Fusion during Mating in C. neoformans}

As a heterothallic basidiomycete, $C$. neoformans can undergo a dimorphic transition to a filamentous growth form by mating and monokaryotic fruiting (Figure 1). Cell fusion is the first step of $\alpha$-a bisexual mating or $\alpha-\alpha$ unisexual mating and can be regulated by the pheromone pathway. In C. neoformans, the Cpk1 (C. neoformans protein kinase 1) MAPK (mitogen-activated protein kinase) signal transduction cascade is a highly-conserved signaling circuit controlling the dimorphism transition during bisexual and unisexual reproduction [54]. However, the downstream targets of the pathway are mostly unknown. Three ZNFs, encoding potential transcription factors, were identified in the process of identification of downstream targets of the Cpk1 MAPK pathway: ZNF1 $\alpha$, located in the mating type locus, Znf2, and Znf3, residing in another genomic region [58-60]. Functional analysis showed that Znf1 is not crucial for Cryptococcus dimorphic hyphal growth because Znf1 mutations in both mating types in the var. neoformans strain backgrounds did not suppress cell fusion or hyphal formation during bisexual and unisexual mating [58]. Protein sequence analysis showed that $\mathrm{Znf2}$ contains four $\mathrm{C}_{2} \mathrm{H}_{2}$ zinc finger domains, indicating that it may be a transcription factor. Loss of Znf2 locks cells in the yeast phase, while overexpression of this regulator drives hyphal growth, indicating that Znf2 is critical for filamentation and hyphal morphogenesis after the cell-cell fusion event during mating [58,61-63]. Lin et al. further proved that Znf2 regulates cryptococcal cellular differentiation in coordination with the chromatin remodeling SWItch/sucrose non-fermentable (SWI/SNF) complex [64]. Znf3 contains three $\mathrm{C}_{2} \mathrm{H}_{2}$ zinc finger domains and sexual reproduction analysis showed that $\mathrm{Znf3}$ plays an essential role in both unisexual and bisexual reproduction [59] (Figure 1). Another study showed that Znf3 promotes cell fusion and pheromone production, not in the pheromone signaling cascade, but in a parallel and independent pathway [59]. Surprisingly, Znf3 was also found to be necessary for mitoticor sex-induced RNAi silencing in Cryptococcus pathogenic species $[59,65]$.

\subsection{ZNFs Regulate Mating Hyphal Growth in C. neoformans}

After fusion of the cells of the opposite mating types during C. neoformans mating, the resulting dikaryotic cell initiates filamentous growth, with two parental nuclei migrating coordinately in the hyphae. During monokaryotic fruiting, two cells of the same mating type, e.g., $\alpha$ cells, fuse to become diploid $\alpha / \alpha$ cells to form the diploid monokaryotic hyphae and initiate filamentous growth. 
The calcineurin signaling pathway and light-sensing pathway are involved in the regulation of hyphae growth in C. neoformans. Calcineurin is a highly-conserved $\mathrm{Ca}^{2+} /$ calmodulin-dependent protein phosphatase and involves stress responses, fungal morphogenesis, and virulence in the three major human fungal pathogens [66,67]. Although it is not essential for initial cell fusion, the calcineurin signaling pathway is vital for hyphal elongation during both the bisexual and unisexual reproduction of $C$. neoformans [55]. Crz1(the calcineurin-responsive zinc finger transcription factor 1 ) is a downstream target of the calcineurin pathway and orchestrates distinct cellular processes in C. neoformans. Fu et al. demonstrated that Crz1 is essential for the sporulation process although it is not required for yeast-hyphal morphological transition during unisexual reproduction of $C$. neoformans [68]. Furthermore, Jung et al. showed that Crz1 plays roles in fungal virulence and stress survival in C. neoformans [69].

Light inhibits mating and monokaryotic fruiting of $C$. neoformans, but the molecular mechanism involved remained unclear. Research from two different groups has shown that filamentation associated with mating and monokaryotic fruiting is explicitly inhibited by blue light [70,71]. C. neoformans orthologues of Neurospora crassa white collar genes (wc-1 and wc-2) in light sensing were identified and named independently as CWC1/BWC1 (Cryptococcus WC-1 homologue/Basidiomycete White Collar 1) and CWC2/BWC2 (Cryptococcus WC-2 homologue/Basidiomycete White Collar 2) [70,71], and a conserved GATA-type zinc finger DNA-binding domain was found in Cwc2/Bwc2 [70]. Functional analysis showed that both $B W C 1$ and $B W C 2$ are essential for mediating light inhibition of mating and haploid fruiting $[70,71]$ and the overexpression of these genes further inhibits filamentation upon light treatment in C. neoformans [70]. Yeh et al. further confirmed that the GATA-type zinc finger DNA-binding domain is crucial for the function of the Cwc2 protein by generating partially-deleted versions of the Cwc2 [72].

\subsection{ZNFs Regulate Basidiospore Formation during Mating or Monokaryotic Fruiting in C. neoformans}

In the late stage of $C$. neoformans mating or monokaryotic fruiting, a basidium formed at the tip of the mating hyphae and four chains of basidiospores are produced on top of the basidium. Signaling pathways, such as the MAPK pathway, ubiquitin-proteasome pathway, and quorum-sensing pathway, are involved in the regulation of basidiospore formation in C. neoformans.

The MAPK cascade, also referred to as the pheromone response pathway, regulates the dimorphic switch in S. cerevisiae, providing a framework for studying morphogenesis in a variety of fungal species. STE12 (Sterile gene 12) encodes a downstream $\mathrm{C}_{2} \mathrm{H}_{2}$-type transcription factor of the pheromone response MAPK cascade, controlling fungal development in S. cerevisiae [73]. STE12 homologs, STE12 $\alpha$ and STE12a, have also been identified in C. neoformans and are encoded by the mating-type locus [74-76]. Although disruption of STE12 $\alpha$ or STE12 $a$ does not abolish pheromone sensing or mating, deletion of the gene results in defective monokaryotic fruiting in C. neoformans $[74,75,77]$.

F-box proteins are the key recognition subunit of the E3 ligase complexes that take part in protein ubiquitination and degradation [78]. The F-box protein (Fbp1) in C. neoformans is essential for fungal sexual reproduction as basidiospore production was blocked in bilateral mating between $f b p 1 \Delta$ mutants, even though normal dikaryotic hyphae were observed during mating [19]. One $\mathrm{C}_{2} \mathrm{H}_{2}$-type zinc finger protein (Zfp1) was identified as a potential substrate of Fbp1 by IP pulldown and LC-MS/MS methods. Functional analysis showed that $\mathrm{Zfp} 1$ is also essential for fungal sexual reproduction as deletion or overexpression of $Z \mathrm{fp} 1$ abolishes meiotic sporulation of $C$. neoformans, which indicates $Z \mathrm{fp} 1$ is essential for regulating meiosis during mating [79].

Bacterial quorum sensing is a well-characterized cell-cell communication system to coordinate population density-dependent changes in behavior $[80,81]$. Recently, Tian et al. identified a fungal quorum-sensing peptide (Qsp1) and showed that it serves as an essential signaling molecule for both forms of sexual reproduction in $\mathrm{C}$. neoformans [82]. The authors further identified the $\mathrm{C}_{2} \mathrm{H}_{2}$-type zinc finger regulator (Cqs2) as a critical component of the Qsp1 signaling cascade during both bisexual and unisexual reproduction. Loss of Cqs2 significantly impaired bisexual and unisexual filamentation and 
abolished meiotic sporulation during both bisexual and unisexual reproduction, indicating ZNFs may play a role in bridging sexual production and the perception of surrounding stresses [82].

\section{ZNFs Regulate the Virulence in C. neoformans}

C. neoformans can infect the human CNS, causing meningitis and killing hundreds of thousands of people each year. Since it is a significant yeast pathogen with genetic tractability, extensive studies have been conducted on the pathogenesis in C. neoformans. Virulence factors and signaling pathways that are crucial for fungal virulence have been identified and extensively studied in C. neoformans $[16,17,83-85]$. ZNFs has also been shown to play an essential role in fungal virulence in C. neoformans $[76,77,86-89]$.

\subsection{ZNFs Regulate Virulence Factors Production in C. neoformans}

As a human fungal pathogen, $C$. neoformans has three classical virulence factors: melanin production, capsule formation and growth at $37^{\circ} \mathrm{C}$, which favors the infection and the pathogenesis of $C$. neoformans. Cryptococcus STE12 $\alpha$ encodes a protein containing both homeodomain and zinc finger regions in MAT $\alpha$ cells of $C$. neoformans [86]. Virulence test showed that the virulence of a ste $12 \alpha$ mutant was significantly reduced in a mouse model as deletion of STE12 $\alpha$ resulted in a reduction in the capsular size of yeast cells in C. neoformans [76,77]. Mutation in the homeodomain of STE12 $\alpha$ reduces DNA binding ability, mating frequency, and haploid fruiting capability but increases virulence and capsule size of yeast cell in C. neoformans. In contrast, mutation in the zinc fingers region also resulted in virulence attenuation, capsule size reduction, and decreased gene expression of capsule associated genes [86]. The second STE12 homolog, STE12a, was also identified in MATa cells in C. neoformans. Deletion of STE12a markedly reduced virulence in mice, as is the case with STE12 $\alpha$ [76]. Northern blot analysis showed that STE12ap regulates mRNA levels of several genes that are important for virulence, including $C$. neoformans laccase gene (CNLAC1) and capsule (CAP) genes. These results clearly showed that mating-type specific genes are not only crucial for sexual reproduction but also play an essential role in virulence of Cryptococcus in host tissue.

Protein kinase C-1 ( $\mathrm{Pkc}$ ) signaling pathways is the primary cellular pathway mediating the cellular responses to environmental stresses. In C. neoformans, mutation of Pkc1 results in defects of cell wall integrity, aberrant capsule, decreased melanogenesis, and inability to grow at $37^{\circ} \mathrm{C}$ [90]. Overexpression of the Pkc1-dependent specificity protein-1 (sp1) encoding gene SP1 in a $p k c 1 \Delta$ mutant rescued the phenotype defects involved in virulence, including cell wall integrity, nitrosative stress, and extracellular capsule production. Besides, deletion of sp1 showed similar phenotype as $p k c 1 \Delta$ mutant, suggesting that the C-terminal ZNFs may shift from calcineurin-dependent to Pkc1-dependent transcription factors in the process of fungal evolution [87].

\subsection{ZNFs Mediate Cryptococcus Crossing the Blood-Brain Barrier}

C. neoformans can invade the CNS to cause cryptococcal meningoencephalitis, most commonly in individuals with impaired immunity. However, the molecular mechanism used by C. neoformans to invade the CNS is not very clear. Vu et al. identified a novel secreted metalloprotease (Mpr1) and demonstrated that it is required for C. neoformans to establish fungal disease in the CNS [88]. Mpr1 belongs to the M36 class of fungalysins unique to fungi, which are generally synthesized as propeptides with relatively long prodomains and highly-conserved regions within their catalytic core. Functional analysis revealed that Mpr1 promotes Cryptococcus to cross the blood-brain barrier (BBB) by facilitating attachment of cryptococci to the endothelium surface. Strikingly, the sole expression of cryptococcal MPR1 in S. cerevisiae endowed the yeast cells with the ability to cross the BBB, which demonstrated that Mpr1 is specific in breaching the BBB and suggested that Mpr1 may function independently of the hyaluronic acid-CD44 pathway in breaching the brain endothelium [88]. Further structure-function analysis of Mpr1 showed that both mutations in the cleavage sites of the prodomain and amino acid substitutions in the HExxH motif resulted in the failure of cryptococci to cross the BBB [91]. The 
proteolytic activity assay showed that the implementation of Mpr1's complete function was dependent on the coordination of zinc with the HExxH motif in the active site of Mpr1 [91].

\subsection{ZNFs Mediate Metal Homeostasis in C. neoformans}

Metals are essential for life and play a central role in the struggle between microbial pathogens and their hosts [92]. The uptake and utilization of the essential metals, such as iron and zinc, are strictly regulated in fungal pathogens. Iron is a critical cue for $C$. neoformans in regulating the elaboration of the polysaccharide capsule during infection. Iron-responsive transcription factor (Cir1) is a GATA-type zinc finger protein regulating iron uptake, iron homeostasis, and virulence factor expression in $C$. neoformans. Mutation of Cir1 results in the loss of capsule production, decreased cell wall integrity and membrane functions, marked growth defect at host body temperature, increased activity of laccase, and complete loss of virulence in both serotype A and D strains in C. neoformans [89]. Further study showed that the abundance of Cir1 is influenced by iron availability [93]. Thus, Cryptococcus can perceive iron as part of the disease process through the zinc finger protein Cir1, which may provide opportunities for antifungal treatment.

The regulation of zinc homeostasis is vital for fungal survival and virulence [94]. To investigate how zinc metabolism affects fungal virulence, the $\mathrm{C}_{2} \mathrm{H}_{2}$-type zinc finger protein Zap1, an ortholog of ZafA and Zap1p in A. fumigatus and S. cerevisiae [94,95], was identified and functionally analyzed in C. gattii. Disruption of Zap1 not only impaired C. gattii growth in zinc-limiting conditions but also decreased its virulence in a murine model of pulmonary infection, indicating ZNFs is required for proper zinc metabolism and plays an essential role in cryptococcal virulence [96].

\section{ZNFs Regulate Stress Resistance in C. neoformans}

C. neoformans is confronted with a variety of host-specific stresses, such as nutrient limitation, temperature shift, changes in oxygen/carbon dioxide levels, oxidative/nitrosative stress, and osmotic stress, upon its infection of the host lung. Signaling pathways or factors involved in the stress response have been identified and extensively studied $[56,97,98]$. ZNFs are also involved in the regulation of the stress response in C. neoformans.

As a calcineurin-responsive zinc finger transcription factor, Crz1 has been proved to govern unisexual reproduction in self-filamentous C. neoformans serotype D strain. In contrast, Crz1 is also essential for cell wall damage repair, biofilm formation, and susceptibility to fluconazole in C. neoformans serotype A strain [99]. Moreover, the Crz1 protein was further proved to be involved in the slowdown of proliferation and survival under reduced aeration [99].

In S. cerevisiae, the $\mathrm{C}_{2} \mathrm{H}_{2}$-type ZNF Mig1 (multicopy inhibitor of GAL gene expression) is a carbon catabolite repressor responsible for the repression of genes involved in alternative carbon metabolism, respiration, and gluconeogenesis [100,101]. In contrast, the Mig1 homologue in C. neoformans is involved in the regulation of mitochondrial functions, such as respiration, tolerance for reactive oxygen species (ROS), and expression of genes involved in iron consumption and acquisition [102]. Remarkably, MIG1 deletion increased fluconazole susceptibility in C. neoformans, highlighting an association between drug susceptibility and mitochondrial dysfunction and providing possible new targets for antifungal drug development [102].

The zinc finger protein Zfp1 is a potential substrate of the F-box protein Fbp1 and is involved in fungal sexual reproduction and virulence in C. neoformans [79]. Stress response assays showed that deletion or overexpression of Zfp1 increased susceptibility to sodium dodecyl sulfate (SDS), but not Congo red, demonstrating that Zfp1 may govern cell membrane integrity, which may be one of the reasons the virulence declined in a murine systemic-infection model [79].

mRNA reprogramming is necessary for successful stress adaptation in C. neoformans. Two small zinc knuckle RNA binding proteins, gluconeogenic growth suppressor 2 (Gis2) and zinc-finger protein 9 (Znf9), were identified by mass spectrometry in C. neoformans. Loss of Gis2 or Znf9 not only increased susceptibility to cobalt chloride, fluconazole, and oxidative stress but also repressed the levels of sterols 
in gis $2 \Delta$ or gis $2 \Delta z n f 9 \Delta$ double mutants although transcriptional induction of C-4 sterol methyl oxidase gene (ERG25) was similar to that of the wild type [103]. These results clearly showed that the zinc finger proteins Gis2 and Znf9 are necessary for stress resistance and ergosterol biosynthesis in C. neoformans.

The ZNFs described in the literature and discussed in this review are summarized in Table 3.

Table 3. Summary of zinc finger proteins described in the literature and discussed in this review.

\begin{tabular}{|c|c|c|c|c|}
\hline Name & Gene ID & Zinc Finger Type & Description and Function & References \\
\hline Bwc2 & CNE01220 & ZnF_C4 & $\begin{array}{l}\text { Sexual filamentation and fungal } \\
\text { virulence }\end{array}$ & {$[70,71]$} \\
\hline Cir1 & CNAG_04864CNJ02920 & $\mathrm{ZnF}_{-} \mathrm{C}_{4}$ & $\begin{array}{c}\text { Iron uptake, iron homeostasis, and } \\
\text { virulence }\end{array}$ & {$[89,93]$} \\
\hline Cqs2 & CNF00370 & Znf_C ${ }_{2} \mathrm{H}_{2}$ & $\begin{array}{l}\text { Important component of the } \\
\text { Qsp1-signaling cascade required for } \\
\text { sexual reproduction }\end{array}$ & [82] \\
\hline Crz1 & CNA01450 & Znf_C ${ }_{2} \mathrm{H}_{2}$ & Regulates the sporulation process & [68] \\
\hline Crz1 & CNAG_00156 & Znf_C ${ }_{2} \mathrm{H}_{2}$ & $\begin{array}{l}\text { Cell integrity; Proliferation and } \\
\text { survival under reduced aeration; } \\
\text { Biofilm formation and susceptibility } \\
\text { to fluconazole. }\end{array}$ & [99] \\
\hline Gat1 & CNAG_00193 & ZnF_C 4 & Nitrogen uptake and metabolism & [104] \\
\hline Gis1 & CNAG_02338 & $\mathrm{Znf}_{-} \mathrm{C}_{2} \mathrm{HC}$ & $\begin{array}{l}\text { Sterol biosynthesis and fluconazole } \\
\text { and oxidative stress sensitivity }\end{array}$ & [103] \\
\hline Mig1 & CNAG_06327 & Znf_C ${ }_{2} \mathrm{H}_{2}$ & $\begin{array}{l}\text { Mitochondrial function and azole } \\
\text { drug susceptibility }\end{array}$ & [102] \\
\hline $\mathrm{sp} 1$ & CNAG_00156 & Znf_C ${ }_{2} \mathrm{H}_{2}$ & $\begin{array}{l}\text { Cell wall stability, nitrosative stress, } \\
\text { extracellular capsule production, and } \\
\text { fungal virulence }\end{array}$ & [87] \\
\hline STE12 $\alpha p$ & CND05810 & Znf_C ${ }_{2} \mathrm{H}_{2}$ & $\begin{array}{l}\text { Haploid filamentation and fungal } \\
\text { virulence }\end{array}$ & {$[74,75,77]$} \\
\hline STE12ap & & Znf_C ${ }_{2} \mathrm{H}_{2}$ & $\begin{array}{l}\text { Capsule formation and fungal } \\
\text { virulence; Capsule-associated genes } \\
\text { expression; }\end{array}$ & {$[76,86]$} \\
\hline Zap1 & CNBG_4460 & Znf_C ${ }_{2} \mathrm{H}_{2}$ & $\begin{array}{c}\text { Growth in zinc-limiting conditions } \\
\text { Expression of ZRT, IRT-like protein } \\
\text { (ZIP) zinc transporters and distinct } \\
\text { zinc-binding proteins; Fungal } \\
\text { virulence }\end{array}$ & [96] \\
\hline Zfp1 & CNAG_07329 & Znf_C ${ }_{2} \mathrm{H}_{2}$ & $\begin{array}{l}\text { Sexual reproduction and fungal } \\
\text { virulence }\end{array}$ & [79] \\
\hline Znf1 & CND05720 & $\mathrm{Znf}_{-} \mathrm{C}_{4} \mathrm{HC}_{3}$ & $\begin{array}{l}\text { Not essential for Cryptococcus } \\
\text { dimorphic hyphal growth }\end{array}$ & [58] \\
\hline Znf2 & CNG02160 & Znf_C ${ }_{2} \mathrm{H}_{2}$ & $\begin{array}{l}\text { Master activator of the yeast to } \\
\text { hyphal transition; Key regulator for } \\
\text { hyphal growth }\end{array}$ & {$[58,61-63]$} \\
\hline Znf3 & CNK01880 & Znf_C ${ }_{2} \mathrm{H}_{2}$ & $\begin{array}{l}\text { Hyphal development during } \\
\text { unisexual and bisexual reproduction }\end{array}$ & [59] \\
\hline Znf3 & CNAG_02700 & Znf_C ${ }_{2} \mathrm{H}_{2}$ & $\begin{array}{c}\text { Link between RNAi silencing and } \\
\text { sexual development }\end{array}$ & [65] \\
\hline Znf9 & CNAG_01273 & Znf_C ${ }_{2} \mathrm{HC}$ & $\begin{array}{l}\text { Sterol biosynthesis; Fluconazole and } \\
\text { oxidative stress sensitivity }\end{array}$ & [103] \\
\hline
\end{tabular}

\section{Conclusions and Future Directions}

ZNFs are one of the most abundant groups of proteins and constitute the largest family of transcription factors that play important roles in prokaryotes and eukaryotes. Recent studies have shown that ZNFs play crucial roles in fungal development and differentiation, ion homeostasis, cell wall integrity, drug susceptibility, and virulence in the human fungal pathogen C. neoformans. In this review, the various roles of ZNFs in C. neoformans were summarized.

Although many ZNFs have been studied and have been shown to play important roles in fungal development, stress response, and virulence in C. neoformans, there are still some areas that should 
be studied: first, the molecular mechanisms that link ZNFs to their biological roles; second, only 20 ZNFs have been identified and functionally analyzed in C. neoformans; third, most of the ZNFs that have been functionally characterized in $C$. neoformans belong to the $\mathrm{C}_{2} \mathrm{H}_{2}$ family; and fourth, although many studies have investigated the role of ZNFs in resistance to antifungal drugs, new antifungal drug development is still an issue. Thus, it is also urgent to investigate the molecular basis of ZNFs in the interaction between $C$. neoformans and host cells since most $Z N F$ s are involved in fungal virulence in C. neoformans. At last, it will be of great interest in the future to see whether some ZNFs could be a target to develop new antifungal drugs.

Supplementary Materials: Supplementary materials can be found at http://www.mdpi.com/1422-0067/21/4/1361/ s1.

Author Contributions: Writing, T.-B.L.; Table preparation, Y.-H.L. All authors have read and agreed to the published version of the manuscript.

Funding: This work is supported by the National Natural Science Foundation of China $(31400133,31970145)$, Chongqing Research Program of Basic Research and Frontier Technology (cstc2017jcyjBX0034), and the Venture \& Innovation Support Program for Chongqing Overseas Returnees (cx2018084).

Acknowledgments: We acknowledge use of the C. neoformans genome sequences at the Broad Institute.

Conflicts of Interest: The authors declare no conflicts of interest.

\section{References}

1. Casadevall, A.; Perfect, J.R. Cryptococcus Neoformans; ASM Press: Washington, DC, USA, 1998.

2. Lin, X.; Heitman, J. The biology of the Cryptococcus neoformans species complex. Annu. Rev. Microbiol. 2006, 60, 69-105. [CrossRef] [PubMed]

3. Idnurm, A.; Bahn, Y.S.; Nielsen, K.; Lin, X.; Fraser, J.A.; Heitman, J. Deciphering the model pathogenic fungus Cryptococcus neoformans. Nat. Rev. Microbiol. 2005, 3, 753-764. [CrossRef] [PubMed]

4. Brown, G.D.; Denning, D.W.; Levitz, S.M. Tackling human fungal infections. Science 2012, 336, 647. [CrossRef] [PubMed]

5. Park, B.J.; Wannemuehler, K.A.; Marston, B.J.; Govender, N.; Pappas, P.G.; Chiller, T.M. Estimation of the current global burden of cryptococcal meningitis among persons living with HIV/AIDS. AIDS 2009, 23, 525-530. [CrossRef]

6. Rajasingham, R.; Smith, R.M.; Park, B.J.; Jarvis, J.N.; Govender, N.P.; Chiller, T.M.; Denning, D.W.; Loyse, A.; Boulware, D.R. Global burden of disease of HIV-associated cryptococcal meningitis: An updated analysis. Lancet Infect. Dis. 2017, 17, 873-881. [CrossRef]

7. Kozel, T.R. Virulence factors of Cryptococcus neoformans. Trends Microbiol. 1995, 3, 295-299. [CrossRef]

8. Kronstad, J.; Jung, W.H.; Hu, G. Beyond the big three: Systematic analysis of virulence factors in Cryptococcus neoformans. Cell Host Microbe 2008, 4, 308-310. [CrossRef]

9. Lin, X.; Hull, C.M.; Heitman, J. Sexual reproduction between partners of the same mating type in Cryptococcus neoformans. Nature 2005, 434, 1017-1021. [CrossRef]

10. Belay, T.; Cherniak, R.; ONeill, E.B.; Kozel, T.R. Serotyping of Cryptococcus neoformans by dot enzyme assay. J. Clin. Microbiol. 1996, 34, 466-470. [CrossRef]

11. Levitz, S.M. The Ecology of Cryptococcus neoformans and the Epidemiology of Cryptococcosis. Rev. Infect. Dis. 1991, 13, 1163-1169. [CrossRef]

12. Franzot, S.P.; Salkin, I.F.; Casadevall, A. Cryptococcus neoformans var. grubii: Separate varietal status for Cryptococcus neoformans serotype A isolates. J. Clin. Microbiol. 1999, 37, 838-840.

13. Springer, D.J.; Chaturvedi, V. Projecting Global Occurrence of Cryptococcus gattii. Emerg. Infect. Dis. 2010, 16, 14-20. [CrossRef]

14. Hagen, F.; Khayhan, K.; Theelen, B.; Kolecka, A.; Polacheck, I.; Sionov, E.; Falk, R.; Parnmen, S.; Lumbsch, H.T.; Boekhout, T. Recognition of seven species in the Cryptococcus gattii/Cryptococcus neoformans species complex. Fungal Genet. Biol. 2015, 78, 16-48. [CrossRef]

15. Kwon-Chung, K.J.; Bennett, J.E.; Wickes, B.L.; Meyer, W.; Cuomo, C.A.; Wollenburg, K.R.; Bicanic, T.A.; Castaneda, E.; Chang, Y.C.; Chen, J.H.; et al. The Case for Adopting the "Species Complex" Nomenclature for the Etiologic Agents of Cryptococcosis. Msphere 2017, 2, e00357-16. [CrossRef] 
16. Kozubowski, L.; Lee, S.C.; Heitman, J. Signalling pathways in the pathogenesis of Cryptococcus. Cell Microbiol. 2009, 11, 370-380. [CrossRef]

17. Lengeler, K.B.; Davidson, R.C.; D’Souza, C.; Harashima, T.; Shen, W.C.; Wang, P.; Pan, X.; Waugh, M.; Heitman, J. Signal transduction cascades regulating fungal development and virulence. Microbiol. Mol. Biol. Rev. 2000, 64, 746-785. [CrossRef]

18. Wang, P.; Heitman, J. Signal transduction cascades regulating mating, filamentation, and virulence in Cryptococcus neoformans. Curr. Opin. Microbiol. 1999, 2, 358-362. [CrossRef]

19. Liu, T.B.; Wang, Y.; Stukes, S.; Chen, Q.; Casadevall, A.; Xue, C. The F-Box protein Fbp1 regulates sexual reproduction and virulence in Cryptococcus neoformans. Eukaryot. Cell 2011, 10, 791-802. [CrossRef]

20. Masso-Silva, J.; Espinosa, V.; Liu, T.B.; Wang, Y.; Xue, C.; Rivera, A. The F-Box Protein Fbp1 Shapes the Immunogenic Potential of Cryptococcus neoformans. mBio 2018, 9, e01828-17. [CrossRef]

21. Laity, J.H.; Lee, B.M.; Wright, P.E. Zinc finger proteins: New insights into structural and functional diversity. Curr. Opin. Struct. Biol. 2001, 11, 39-46. [CrossRef]

22. MacPherson, S.; Larochelle, M.; Turcotte, B. A fungal family of transcriptional regulators: The zinc cluster proteins. Microbiol. Mol. Biol. Rev. 2006, 70, 583-604. [CrossRef]

23. Bhat, P.J.; Murthy, T.V. Transcriptional control of the GAL/MEL regulon of yeast Saccharomyces cerevisiae: Mechanism of galactose-mediated signal transduction. Mol. Microbiol. 2001, 40, 1059-1066. [CrossRef] [PubMed]

24. Miller, J.; Mclachlan, A.D.; Klug, A. Repetitive Zinc-Binding Domains in the Protein Transcription Factor Iiia from Xenopus Oocytes. EMBO J. 1985, 4, 1609-1614. [CrossRef] [PubMed]

25. Lee, M.S.; Gippert, G.P.; Soman, K.V.; Case, D.A.; Wright, P.E. Three-dimensional solution structure of a single zinc finger DNA-binding domain. Science 1989, 245, 635-637. [CrossRef] [PubMed]

26. Berg, J.M.; Shi, Y. The galvanization of biology: A growing appreciation for the roles of zinc. Science 1996, 271, 1081-1085. [CrossRef] [PubMed]

27. Dai, K.S.; Liew, C.C. Characterization of a novel gene encoding zinc finger domains identified from expressed sequence tags (ESTs) of a human heart cDNA database. J. Mol. Cell. Cardiol. 1998, 30, 2365-2375. [CrossRef]

28. Gupta, S.K.; Rai, A.K.; Kanwar, S.S.; Sharma, T.R. Comparative analysis of zinc finger proteins involved in plant disease resistance. PLoS ONE 2012, 7, e42578. [CrossRef]

29. Summers, M.F. Zinc finger motif for single-stranded nucleic acids? Investigations by nuclear magnetic resonance. J. Cell. Biochem. 1991, 45, 41-48. [CrossRef]

30. Bombarda, E.; Grell, E.; Roques, B.P.; Mely, Y. Molecular mechanism of the Zn2+-induced folding of the distal CCHC finger motif of the HIV-1 nucleocapsid protein. Biophys. J. 2007, 93, 208-217. [CrossRef]

31. Matsui, T.; Kodera, Y.; Endoh, H.; Miyauchi, E.; Komatsu, H.; Sato, K.; Tanaka, T.; Kohno, T.; Maeda, T. RNA recognition mechanism of the minimal active domain of the human immunodeficiency virus type-2 nucleocapsid protein. J. Biochem. 2007, 141, 269-277. [CrossRef]

32. Narayanan, N.; Gorelick, R.J.; DeStefano, J.J. Structure/function mapping of amino acids in the N-terminal zinc finger of the human immunodeficiency virus type 1 nucleocapsid protein: Residues responsible for nucleic acid helix destabilizing activity. Biochemistry 2006, 45, 12617-12628. [CrossRef] [PubMed]

33. Clay, N.K.; Nelson, T. The recessive epigenetic swellmap mutation affects the expression of two step II splicing factors required for the transcription of the cell proliferation gene STRUWWELPETER and for the timing of cell cycle arrest in the Arabidopsis leaf. Plant Cell 2005, 17, 1994-2008. [CrossRef]

34. Wang, D.; Guo, Y.; Wu, C.; Yang, G.; Li, Y.; Zheng, C. Genome-wide analysis of CCCH zinc finger family in Arabidopsis and rice. BMC Genom. 2008, 9, 44. [CrossRef]

35. DuBois, R.N.; McLane, M.W.; Ryder, K.; Lau, L.F.; Nathans, D. A growth factor-inducible nuclear protein with a novel cysteine/histidine repetitive sequence. J. Biol. Chem. 1990, 265, 19185-19191. [PubMed]

36. Li, W.T.; He, M.; Wang, J.; Wang, Y.P. Zinc finger protein (ZFP) in plants-A review. Plant Omics 2013, 6, $474-480$.

37. Omichinski, J.G.; Clore, G.M.; Schaad, O.; Felsenfeld, G.; Trainor, C.; Appella, E.; Stahl, S.J.; Gronenborn, A.M. NMR structure of a specific DNA complex of Zn-containing DNA binding domain of GATA-1. Science 1993, 261, 438-446. [CrossRef] [PubMed]

38. Kosarev, P.; Mayer, K.F.; Hardtke, C.S. Evaluation and classification of RING-finger domains encoded by the Arabidopsis genome. Genome Biol. 2002, 3, research0016-1. [CrossRef] [PubMed] 
39. Stone, S.L.; Hauksdottir, H.; Troy, A.; Herschleb, J.; Kraft, E.; Callis, J. Functional analysis of the RING-type ubiquitin ligase family of Arabidopsis. Plant Physiol. 2005, 137, 13-30. [CrossRef] [PubMed]

40. Lim, S.D.; Yim, W.C.; Moon, J.C.; Kim, D.S.; Lee, B.M.; Jang, C.S. A gene family encoding RING finger proteins in rice: Their expansion, expression diversity, and co-expressed genes. Plant Mol. Biol. 2010, 72, 369-380. [CrossRef] [PubMed]

41. Lorick, K.L.; Jensen, J.P.; Fang, S.; Ong, A.M.; Hatakeyama, S.; Weissman, A.M. RING fingers mediate ubiquitin-conjugating enzyme (E2)-dependent ubiquitination. Proc. Natl. Acad. Sci. USA 1999, 96, 11364-11369. [CrossRef]

42. Deshaies, R.J.; Joazeiro, C.A. RING domain E3 ubiquitin ligases. Annu. Rev. Biochem. 2009, 78, 399-434. [CrossRef] [PubMed]

43. Freyd, G.; Kim, S.K.; Horvitz, H.R. Novel cysteine-rich motif and homeodomain in the product of the Caenorhabditis elegans cell lineage gene lin-11. Nature 1990, 344, 876-879. [CrossRef] [PubMed]

44. Marmorstein, R.; Carey, M.; Ptashne, M.; Harrison, S.C. DNA Recognition by Gal4-Structure of a Protein DNA Complex. Nature 1992, 356, 408-414. [CrossRef] [PubMed]

45. Borden, K.L.; Freemont, P.S. The RING finger domain: A recent example of a sequence-structure family. Curr. Opin. Struct. Biol. 1996, 6, 395-401. [CrossRef]

46. Gabig, T.G.; Mantel, P.L.; Rosli, R.; Crean, C.D. Requiem: A novel zinc finger gene essential for apoptosis in myeloid cells. J. Biol. Chem. 1994, 269, 29515-29519.

47. Koken, M.H.; Saib, A.; de The, H. A C4HC3 zinc finger motif. Comptes Rendus Acad. Sci. III 1995, 318, 733-739.

48. Evans, R.M. The Steroid and Thyroid-Hormone Receptor Superfamily. Science 1988, 240, 889-895. [CrossRef]

49. Krishna, S.S.; Majumdar, I.; Grishin, N.V. Structural classification of zinc fingers. Nucleic Acids Res. 2003, 31, 532-550. [CrossRef]

50. Kluska, K.; Adamczyk, J.; Krezel, A. Metal binding properties, stability and reactivity of zinc fingers. Coord. Chem. Rev. 2018, 367, 18-64. [CrossRef]

51. Gray, K.A.; Yates, B.; Seal, R.L.; Wright, M.W.; Bruford, E.A. Genenames.org: The HGNC resources in 2015. Nucleic Acids Res. 2015, 43, D1079-D1085. [CrossRef]

52. Loftus, B.J.; Fung, E.; Roncaglia, P.; Rowley, D.; Amedeo, P.; Bruno, D.; Vamathevan, J.; Miranda, M.; Anderson, I.J.; Fraser, J.A.; et al. The genome of the basidiomycetous yeast and human pathogen Cryptococcus neoformans. Science 2005, 307, 1321-1324. [CrossRef]

53. Janbon, G.; Ormerod, K.L.; Paulet, D.; Byrnes, E.J., 3rd; Yadav, V.; Chatterjee, G.; Mullapudi, N.; Hon, C.C.; Billmyre, R.B.; Brunel, F.; et al. Analysis of the genome and transcriptome of Cryptococcus neoformans var. grubii reveals complex RNA expression and microevolution leading to virulence attenuation. PLoS Genet. 2014, 10, e1004261.

54. Davidson, R.C.; Nichols, C.B.; Cox, G.M.; Perfect, J.R.; Heitman, J. A MAP kinase cascade composed of cell type specific and non-specific elements controls mating and differentiation of the fungal pathogen Cryptococcus neoformans. Mol. Microbiol. 2003, 49, 469-485. [CrossRef] [PubMed]

55. Cruz, M.C.; Fox, D.S.; Heitman, J. Calcineurin is required for hyphal elongation during mating and haploid fruiting in Cryptococcus neoformans. EMBO J. 2001, 20, 1020-1032. [CrossRef] [PubMed]

56. Jung, K.W.; Bahn, Y.S. The Stress-Activated Signaling (SAS) Pathways of a Human Fungal Pathogen, Cryptococcus neoformans. Mycobiology 2009, 37, 161-170. [CrossRef]

57. Bahn, Y.S.; Kojima, K.; Cox, G.M.; Heitman, J. Specialization of the HOG pathway and its impact on differentiation and virulence of Cryptococcus neoformans. Mol. Biol. Cell 2005, 16, 2285-2300. [CrossRef]

58. Lin, X.; Jackson, J.C.; Feretzaki, M.; Xue, C.; Heitman, J. Transcription factors Mat2 and Znf2 operate cellular circuits orchestrating opposite- and same-sex mating in Cryptococcus neoformans. PLoS Genet. 2010, 6, e1000953. [CrossRef]

59. Feretzaki, M.; Heitman, J. Genetic circuits that govern bisexual and unisexual reproduction in Cryptococcus neoformans. PLoS Genet. 2013, 9, e1003688. [CrossRef]

60. Lengeler, K.B.; Fox, D.S.; Fraser, J.A.; Allen, A.; Forrester, K.; Dietrich, F.S.; Heitman, J. Mating-type locus of Cryptococcus neoformans: A step in the evolution of sex chromosomes. Eukaryot. Cell 2002, 1, 704-718. [CrossRef]

61. Wang, L.; Zhai, B.; Lin, X. The link between morphotype transition and virulence in Cryptococcus neoformans. PLoS Pathog. 2012, 8, e1002765. [CrossRef] 
62. Zhai, B.; Zhu, P.; Foyle, D.; Upadhyay, S.; Idnurm, A.; Lin, X. Congenic strains of the filamentous form of Cryptococcus neoformans for studies of fungal morphogenesis and virulence. Infect. Immun. 2013, 81, 2626-2637. [CrossRef] [PubMed]

63. Lin, J.; Idnurm, A.; Lin, X. Morphology and its underlying genetic regulation impact the interaction between Cryptococcus neoformans and its hosts. Med. Mycol. 2015, 53, 493-504. [CrossRef] [PubMed]

64. Lin, J.; Zhao, Y.; Ferraro, A.R.; Yang, E.; Lewis, Z.A.; Lin, X. Transcription factor Znf2 coordinates with the chromatin remodeling SWI/SNF complex to regulate cryptococcal cellular differentiation. Commun. Biol. 2019, 2, 412. [CrossRef]

65. Feretzaki, M.; Billmyre, R.B.; Clancey, S.A.; Wang, X.Y.; Heitman, J. Gene Network Polymorphism Illuminates Loss and Retention of Novel RNAi Silencing Components in the Cryptococcus Pathogenic Species Complex. PLoS Genet. 2016, 12, e1005868. [CrossRef] [PubMed]

66. Fox, D.S.; Heitman, J. Good fungi gone bad: The corruption of calcineurin. Bioessays 2002, 24, 894-903. [CrossRef]

67. Steinbach, W.J.; Reedy, J.L.; Cramer, R.A., Jr.; Perfect, J.R.; Heitman, J. Harnessing calcineurin as a novel anti-infective agent against invasive fungal infections. Nat. Rev. Microbiol. 2007, 5, 418-430. [CrossRef]

68. Fu, C.; Donadio, N.; Cardenas, M.E.; Heitman, J. Dissecting the Roles of the Calcineurin Pathway in Unisexual Reproduction, Stress Responses, and Virulence in Cryptococcus deneoformans. Genetics 2018, 208, 639-653. [CrossRef]

69. Jung, W.H.; Son, Y.E.; Oh, S.H.; Fu, C.; Kim, H.S.; Kwak, J.H.; Cardenas, M.E.; Heitman, J.; Park, H.S. Had1 Is Required for Cell Wall Integrity and Fungal Virulence in Cryptococcus neoformans. G3 Genes Genomes Genet. 2018, 8, 643-652. [CrossRef]

70. Lu, Y.K.; Sun, K.H.; Shen, W.C. Blue light negatively regulates the sexual filamentation via the Cwc1 and Cwc2 proteins in Cryptococcus neoformans. Mol. Microbiol. 2005, 56, 480-491. [CrossRef]

71. Idnurm, A.; Heitman, J. Light controls growth and development via a conserved pathway in the fungal kingdom. PLoS Biol. 2005, 3, 615-626. [CrossRef]

72. Yeh, Y.L.; Lin, Y.S.; Su, B.J.; Shen, W.C. A screening for suppressor mutants reveals components involved in the blue light-inhibited sexual filamentation in Cryptococcus neoformans. Fungal Genet. Biol. 2009, 46, $42-54$. [CrossRef] [PubMed]

73. Roberts, R.L.; Fink, G.R. Elements of a Single Map Kinase Cascade in Saccharomyces cerevisiae Mediate 2 Developmental Programs in the Same Cell-Type-Mating and Invasive Growth. Genes Dev. 1994, 8, 2974-2985. [CrossRef] [PubMed]

74. Wickes, B.L.; Edman, U.; Edman, J.C. The Cryptococcus neoformans STE12alpha gene: A putative Saccharomyces cerevisiae STE12 homologue that is mating type specific. Mol. Microbiol. 1997, 26, 951-960. [CrossRef] [PubMed]

75. Yue, C.; Cavallo, L.M.; Alspaugh, J.A.; Wang, P.; Cox, G.M.; Perfect, J.R.; Heitman, J. The STE12alpha homolog is required for haploid filamentation but largely dispensable for mating and virulence in Cryptococcus neoformans. Genetics 1999, 153, 1601-1615. [PubMed]

76. Chang, Y.C.; Penoyer, L.A.; Kwon-Chung, K.J. The second STE12 homologue of Cryptococcus neoformans is MATa-specific and plays an important role in virulence. Proc. Natl. Acad. Sci. USA 2001, 98, 3258-3263. [CrossRef] [PubMed]

77. Chang, Y.C.; Wickes, B.L.; Miller, G.F.; Penoyer, L.A.; Kwon-Chung, K.J. Cryptococcus neoformans STE12alpha regulates virulence but is not essential for mating. J. Exp. Med. 2000, 191, 871-882. [CrossRef]

78. Jonkers, W.; Rep, M. Lessons from fungal F-box proteins. Eukaryot. Cell 2009, 8, 677-695. [CrossRef]

79. Fan, C.L.; Han, L.T.; Jiang, S.T.; Chang, A.N.; Zhou, Z.Y.; Liu, T.B. The Cys2His2 zinc finger protein Zfp1 regulates sexual reproduction and virulence in Cryptococcus neoformans. Fungal Genet. Biol. 2019, 124, 59-72. [CrossRef]

80. Abisado, R.G.; Benomar, S.; Klaus, J.R.; Dandekar, A.A.; Chandler, J.R. Bacterial Quorum Sensing and Microbial Community Interactions. mBio 2018, 9, e02331-17. [CrossRef]

81. Whiteley, M.; Diggle, S.P.; Greenberg, E.P. Progress in and promise of bacterial quorum sensing research. Nature 2017, 551, 313-320. [CrossRef]

82. Tian, X.; He, G.J.; Hu, P.; Chen, L.; Tao, C.; Cui, Y.L.; Shen, L.; Ke, W.; Xu, H.; Zhao, Y.; et al. Cryptococcus neoformans sexual reproduction is controlled by a quorum sensing peptide. Nat. Microbiol. 2018, 3, 698-707. [CrossRef] [PubMed] 
83. Bahn, Y.S.; Jung, K.W. Stress signaling pathways for the pathogenicity of Cryptococcus. Eukaryot. Cell 2013, 12, 1564-1577. [CrossRef] [PubMed]

84. Choi, J.; Jung, W.H.; Kronstad, J.W. The cAMP/protein kinase A signaling pathway in pathogenic basidiomycete fungi: Connections with iron homeostasis. J. Microbiol. 2015, 53, 579-587. [CrossRef] [PubMed]

85. Roman, E.; Arana, D.M.; Nombela, C.; Alonso-Monge, R.; Pla, J. MAP kinase pathways as regulators of fungal virulence. Trends Microbiol. 2007, 15, 181-190. [CrossRef]

86. Chang, Y.C.; Wright, L.C.; Tscharke, R.L.; Sorrell, T.C.; Wilson, C.F.; Kwon-Chung, K.J. Regulatory roles for the homeodomain and $\mathrm{C} 2 \mathrm{H} 2$ zinc finger regions of Cryptococcus neoformans Ste12alphap. Mol. Microbiol. 2004, 53, 1385-1396. [CrossRef]

87. Adler, A.; Park, Y.D.; Larsen, P.; Nagarajan, V.; Wollenberg, K.; Qiu, J.; Myers, T.G.; Williamson, P.R. A novel specificity protein 1 (SP1)-like gene regulating protein kinase $\mathrm{C}-1$ (Pkc1)-dependent cell wall integrity and virulence factors in Cryptococcus neoformans. J. Biol. Chem. 2011, 286, 20977-20990. [CrossRef]

88. Vu, K.; Tham, R.; Uhrig, J.P.; Thompson, G.R., 3rd; Na Pombejra, S.; Jamklang, M.; Bautos, J.M.; Gelli, A. Invasion of the central nervous system by Cryptococcus neoformans requires a secreted fungal metalloprotease. mBio 2014, 5, e01101-14. [CrossRef]

89. Jung, W.H.; Sham, A.; White, R.; Kronstad, J.W. Iron regulation of the major virulence factors in the AIDS-associated pathogen Cryptococcus neoformans. PLoS Biol. 2006, 4, e410. [CrossRef]

90. Gerik, K.J.; Bhimireddy, S.R.; Ryerse, J.S.; Specht, C.A.; Lodge, J.K. PKC1 is essential for protection against both oxidative and nitrosative stresses, cell integrity, and normal manifestation of virulence factors in the pathogenic fungus Cryptococcus neoformans. Eukaryot. Cell 2008, 7, 1685-1698. [CrossRef]

91. Na Pombejra, S.; Jamklang, M.; Uhrig, J.P.; Vu, K.; Gelli, A. The structure-function analysis of the Mpr1 metalloprotease determinants of activity during migration of fungal cells across the blood-brain barrier. PLoS ONE 2018, 13, e0203020. [CrossRef]

92. Gerwien, F.; Skrahina, V.; Kasper, L.; Hube, B.; Brunke, S. Metals in fungal virulence. FEMS Microbiol. Rev. 2018, 42, fux050. [CrossRef] [PubMed]

93. Jung, W.H.; Kronstad, J.W. Iron influences the abundance of the iron regulatory protein Cir1 in the fungal pathogen Cryptococcus neoformans. FEBS Lett. 2011, 585, 3342-3347. [CrossRef] [PubMed]

94. Moreno, M.A.; Ibrahim-Granet, O.; Vicentefranqueira, R.; Amich, J.; Ave, P.; Leal, F.; Latge, J.P.; Calera, J.A. The regulation of zinc homeostasis by the ZafA transcriptional activator is essential for Aspergillus fumigatus virulence. Mol. Microbiol. 2007, 64, 1182-1197. [CrossRef] [PubMed]

95. Zhao, H.; Eide, D.J. Zap1p, a metalloregulatory protein involved in zinc-responsive transcriptional regulation in Saccharomyces cerevisiae. Mol. Cell. Biol. 1997, 17, 5044-5052. [CrossRef] [PubMed]

96. Schneider Rde, O.; Fogaca Nde, S.; Kmetzsch, L.; Schrank, A.; Vainstein, M.H.; Staats, C.C. Zap1 regulates zinc homeostasis and modulates virulence in Cryptococcus gattii. PLoS ONE 2012, 7, e43773. [CrossRef] [PubMed]

97. So, Y.S.; Lee, D.G.; Idnurm, A.; Ianiri, G.; Bahn, Y.S. The TOR Pathway Plays Pleiotropic Roles in Growth and Stress Responses of the Fungal Pathogen Cryptococcus neoformans. Genetics 2019, 212, 1241-1258. [CrossRef]

98. Dichtl, K.; Samantaray, S.; Wagener, J. Cell wall integrity signalling in human pathogenic fungi. Cell Microbiol. 2016, 18, 1228-1238. [CrossRef]

99. Moranova, Z.; Virtudazo, E.; Hricova, K.; Ohkusu, M.; Kawamoto, S.; Husickova, V.; Raclavsky, V. The CRZ1/SP1-like gene links survival under limited aeration, cell integrity and biofilm formation in the pathogenic yeast Cryptococcus neoformans. Biomed. Pap. Med. Fac. Univ. Palacky Olomouc 2014, 158, 212-220. [CrossRef]

100. Karunanithi, S.; Cullen, P.J. The filamentous growth MAPK Pathway Responds to Glucose Starvation Through the Mig1/2 transcriptional repressors in Saccharomyces cerevisiae. Genetics 2012, 192, 869-887. [CrossRef]

101. Conrad, M.; Schothorst, J.; Kankipati, H.N.; Van Zeebroeck, G.; Rubio-Texeira, M.; Thevelein, J.M. Nutrient sensing and signaling in the yeast Saccharomyces cerevisiae. FEMS Microbiol. Rev. 2014, 38, 254-299. [CrossRef]

102. Caza, M.; Hu, G.; Price, M.; Perfect, J.R.; Kronstad, J.W. The Zinc Finger Protein Mig1 Regulates Mitochondrial Function and Azole Drug Susceptibility in the Pathogenic Fungus Cryptococcus neoformans. mSphere 2016, 1, e00080-15. [CrossRef] [PubMed] 
103. Leipheimer, J.; Bloom, A.L.M.; Baumstark, T.; Panepinto, J.C. CNBP Homologues Gis2 and Znf9 Interact with a Putative G-Quadruplex-Forming 3' Untranslated Region, Altering Polysome Association and Stress Tolerance in Cryptococcus neoformans. mSphere 2018, 3, e00201-18. [CrossRef] [PubMed]

104. Kmetzsch, L.; Staats, C.C.; Simon, E.; Fonseca, F.L.; Oliveira, D.L.; Joffe, L.S.; Rodrigues, J.; Lourenco, R.F.; Gomes, S.L.; Nimrichter, L.; et al. The GATA-type transcriptional activator Gat1 regulates nitrogen uptake and metabolism in the human pathogen Cryptococcus neoformans. Fungal Genet. Biol. 2011, 48, 192-199. [CrossRef] [PubMed]

(C) 2020 by the authors. Licensee MDPI, Basel, Switzerland. This article is an open access article distributed under the terms and conditions of the Creative Commons Attribution (CC BY) license (http://creativecommons.org/licenses/by/4.0/). 